\title{
ANALYTICAL STUDY FOR THE PRISON DESIGN IN EGYPT ACCORDING TO HUMAN RIGHTS ORGANIZATION CONSIDERATIONS
}

\author{
Radwa Emam Soliman 1, Zeinab El-Razaz 2, Mohammed Saif EL-Nasr 3 \\ 1 Assistant lecturer, 2 Professor, 3 Assistant Professor \\ Architecture Dep., Faculty of Engineering-Mattaria, Helwan University
}

\begin{abstract}
This research is an attempt to analyzing an Egyptian prison according to human rights considerations and extracting a future design vision based on those considerations. In this research, an analytical approach will be conducted in the form of a group of activities as reviewing many types of literature and references including different types of books, periodicals, conference proceedings, various thesis, published and non published essays, papers, internet sites and interviews for inference knowledge and concepts.

The research outcome is not a classification rule, but an elaborating proposition, derived from the analysis of the gained knowledge, highlighting the constant changes in the design of the prison buildings according to human rights considerations.
\end{abstract}

Keywords: prison design - Human Rights Organization considerations 


\section{1- Introduction:}

The prison building is a place for the residence of those who violated the laws, and despite being a criminal but a human being, he should live in a place that enjoys his human rights, therefore the prison building should be engineered in accordance with the considerations contained in human rights agreements in general and agreements and principles of rights The prisoner in particular.

While in the ancient Roman Empire, officials mastered how to punish the perpetrators. They put the cells under the ground, tied their hands and locked them in very narrow corridors, causing them to suffocate for an indefinite period of time, and then used as wrestlers. $]^{1}[$

The deprivation of liberty was not defined as a punishment at the time, but prisons had to house persons sentenced to corporal punishment pending execution, pending trial, as well as the occasional use of prisons for political purposes, where they were held for those who, For his authority, they have been in prison for unlimited periods $]^{2}[$

Thus, the implementation of precautionary measures representing criminal punishment must aim at addressing the factors that led to the crime, whether linked to the offender or other external factors ${ }^{3}$

The aim of the punishment in the medieval ages was to purge the offender, and the Christian religion had an impact on the target. The principles of tolerance and compassion advocated by Christianity to sign and implement sanctions have reduced or reduced the torture of perpetrators. The sanctions remained strong and inhumane.

In this period of history, the state has neglected prisons. The buildings were dark and unhealthy, where torture and torture were practiced, and there was no humane treatment. $]^{4}[$

In the modern ages, some reform movements that dealt with criminal law as a whole emerged from the legislative stage to the executive branch through the judiciary $]^{5}[$

\subsection{Problem Definition:}

In spite of reforms in designing of prison building, many societies fail to recognize the value and need for advance planning. Once they recognize that building a new prison facility is inevitable, they often want to move quickly to a solution. It may seem that choosing an architect to start drawing plans or purchasing a prototype design or signing a construction contract design based on budget strength and bed assessment needs is the fastest choice for many communities. Therefore, when designing the prison building, it should be taken into consideration standards of the Human Rights Organization the current research aimed at analyzing an Egyptian prison according to these considerations, and extracting a future design vision based on those considerations. 


\subsection{Objectives:}

Analyze an analytical study of the design of Tora Prison based on the consideration of the Human Rights Organization to verify the availability of these considerations and standards in the design of the building.

\subsection{Methodology:}

In this research, an analytical approach will be conducted in the form of a group of activities as reviewing many types of literature and references including different types of books, periodicals, conference proceedings, various thesis, published and non published essays, papers, internet sites and interviews for inference knowledge and concepts.

\section{Literature Review:}

The Human Rights Association for the Assistance of Prisoners (HRAAP) legally registered under number 1820/2003, works towards upgrading the penal systems in Egypt. It also monitors and overlooks the conditions of Egyptian prisons, by offering legal support to prisoners, calling upon authorities to improve prison conditions, encouraging researchers to conduct analytical and applied studies on the prisons' conditions.

\subsection{Building Design According to Human Rights Considerations:}

In addition to the specific recommendations contained in this document, development teams should attempt to design the prison facilities in a manner that considers the psychological health of the prisoner and creates a positive and mentally stimulating environment for prisoners. In contrast to traditional approaches, innovative prison design tries to make facilities less "prison-like" and more focused on the rehabilitation of prisoners. Relevant considerations include ${ }^{6}$ :

Table 1: Shows the Human Rights Considerations

\begin{tabular}{|c|c|c|}
\hline \multirow{3}{*}{$\begin{array}{l}\text { PRE-DESIGN } \\
\text { PLANNING: }\end{array}$} & \multicolumn{2}{|c|}{ REASONS FOR PLANNING } \\
\hline & \multicolumn{2}{|c|}{ The two phases of pre-design planning } \\
\hline & \multicolumn{2}{|c|}{ When planning works well: } \\
\hline \multirow{8}{*}{$\begin{array}{l}\text { Site Consideration and } \\
\text { Selection: }\end{array}$} & \multirow[t]{4}{*}{ Site Size } & BUILDING AREA \\
\hline & & $\begin{array}{l}\text { BUILDING } \\
\text { EXPANSION }\end{array}$ \\
\hline & & OUTDOOR SPACES \\
\hline & & $\begin{array}{l}\text { ACCESS TO THE } \\
\text { SITE: }\end{array}$ \\
\hline & \multirow[t]{3}{*}{ Site Planning } & A campus system \\
\hline & & A cluster system \\
\hline & & integrated prison \\
\hline & \multicolumn{2}{|c|}{ DESIGN AND CONSTRUCTION PHASING } \\
\hline MASTER PLANNING & \multicolumn{2}{|l|}{ Indoor spaces: } \\
\hline
\end{tabular}


Mohammed Saif EL-Nasr/Engineering Research Journal 166 (June 2020) A18-A33

\begin{tabular}{|c|c|c|}
\hline \multirow{3}{*}{$\begin{array}{l}\text { CONSIDERATIONS FOR THE } \\
\text { DESIGN OF HUMANE } \\
\text { PRISONS: }\end{array}$} & \multicolumn{2}{|l|}{$\begin{array}{l}\text { Natural lighting: } \\
\text { Sound: }\end{array}$} \\
\hline & \multicolumn{2}{|l|}{ Views } \\
\hline & \multicolumn{2}{|l|}{ Outdoor spaces: } \\
\hline \multirow[t]{7}{*}{ Prisoner Accommodation: } & \multirow{7}{*}{$\begin{array}{l}\text { Housing (Prisoner } \\
\text { accommodation): }\end{array}$} & Single and shared cells: \\
\hline & & Dormitories: \\
\hline & & SOLITARY CONFINEMENT \\
\hline & & $\begin{array}{l}\text { MOTHER AND BABY UNITS } \\
\text { (MBU): }\end{array}$ \\
\hline & & $\begin{array}{l}\text { Sanitary and bathing } \\
\text { installations: }\end{array}$ \\
\hline & & Dayroom \\
\hline & & Yard \\
\hline \multirow[t]{11}{*}{ PRISONER FACILITIES } & \multicolumn{2}{|l|}{ VISITS: } \\
\hline & \multirow[t]{2}{*}{ EDUCATION } & EDUCATION (CLASSROOMS) \\
\hline & & EDUCATION (LIBRARY): \\
\hline & \multicolumn{2}{|l|}{ Workshops (and storage): } \\
\hline & \multirow{2}{*}{ HEALTHCARE AND HYGIENE } & HEALTHCARE FACILITIES \\
\hline & & HYGIENIC FACILITIES \\
\hline & \multirow[t]{2}{*}{ FOOD AND DRINK } & KITCHEN AREAS: \\
\hline & & MESS AREAS: \\
\hline & Prisoner Commissary & \\
\hline & \multicolumn{2}{|l|}{ PHYSICAL RECREATION } \\
\hline & \multicolumn{2}{|l|}{ OTHER FACILITIES: } \\
\hline \multirow[t]{5}{*}{ PRISON SUPPORT } & \multicolumn{2}{|l|}{ SECURITY: } \\
\hline & \multicolumn{2}{|l|}{ STAFF } \\
\hline & \multicolumn{2}{|l|}{ MAINTENANCE DEPARTMENT } \\
\hline & \multicolumn{2}{|l|}{ CENTRAL STORES } \\
\hline & \multicolumn{2}{|l|}{ ADMINISTRATION } \\
\hline
\end{tabular}

\section{3- Case Study:}

The researcher will analyze an analytical study of the design of Millhaven Institution - Island 2012 and Tora Prison based on the consideration of the Human Rights Organization to verify the availability of these considerations and standards in the design of the building.

\subsection{Millhaven Institution - Island 2012:}

\section{3-1-1 Site consideration:}

The prison is located on the outskirts of the capital Reykjavik in Iceland. The size of the building is about 3.700 square meters and the building is 37.410 square meters. The owner of the building is the Government of Iceland. The prison began operations in 2016. 


\subsection{2. overview:}

Arkís architectural firm designed a winning proposal for the construction of the prison. Arkís then chose Verkís to design lighting, electricity and security systems for the project. Holmechidi Prison is a modern facility and has been designed to the latest building standards with the aim of attaining BREEAM certification as "very good". The building is a prison, a short prison and a women's prison with a total of 56 cells.

\subsubsection{The main architectural and analytical study of the prison:}

Millhaven Institution is based on a radial design model where offender accommodations are direct observation living units radiating off a central control post. All offender movement is conducted through this central control post. Millhaven consists of three main living units, a segregation unit and a hospital wing. There are approximately 120 men per unit. Units have two levels. Ranges are double-sided and have hydraulically locking metal doors, housing two inmates per cell.

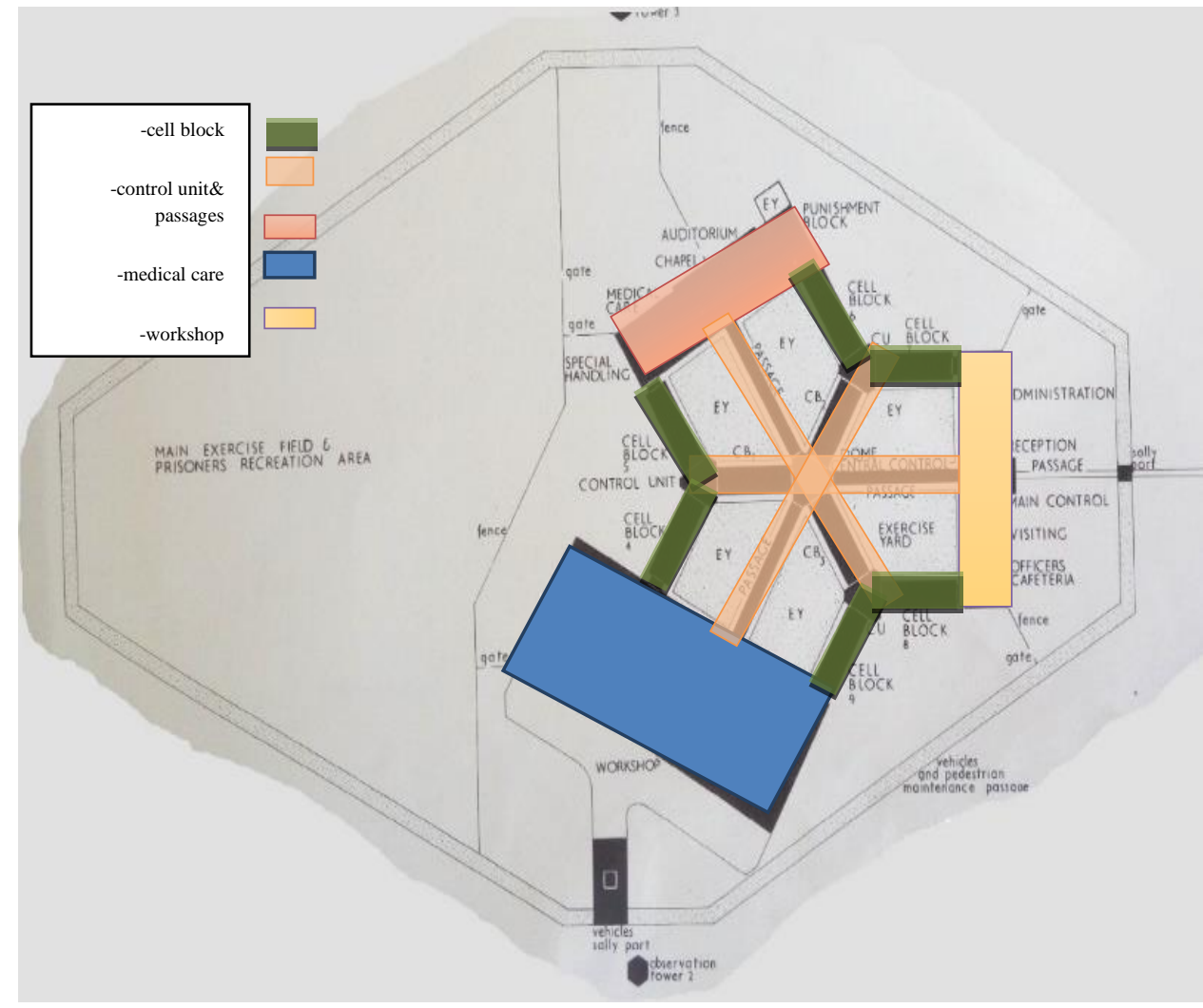

Figure 1 Millhaven Institution 


\subsection{4 master planning:}

The Hólmsheiði Prison, with its flat and unseen landscape on the outskirts of Reykjavik, is a low Crusader building with a slight circular grace at its crossing. This is the guard post, and 56 cells are arranged around courtyards on each of the building's arms. The cells themselves are reminiscent of the hotel rooms, albeit happily furnished, each with a

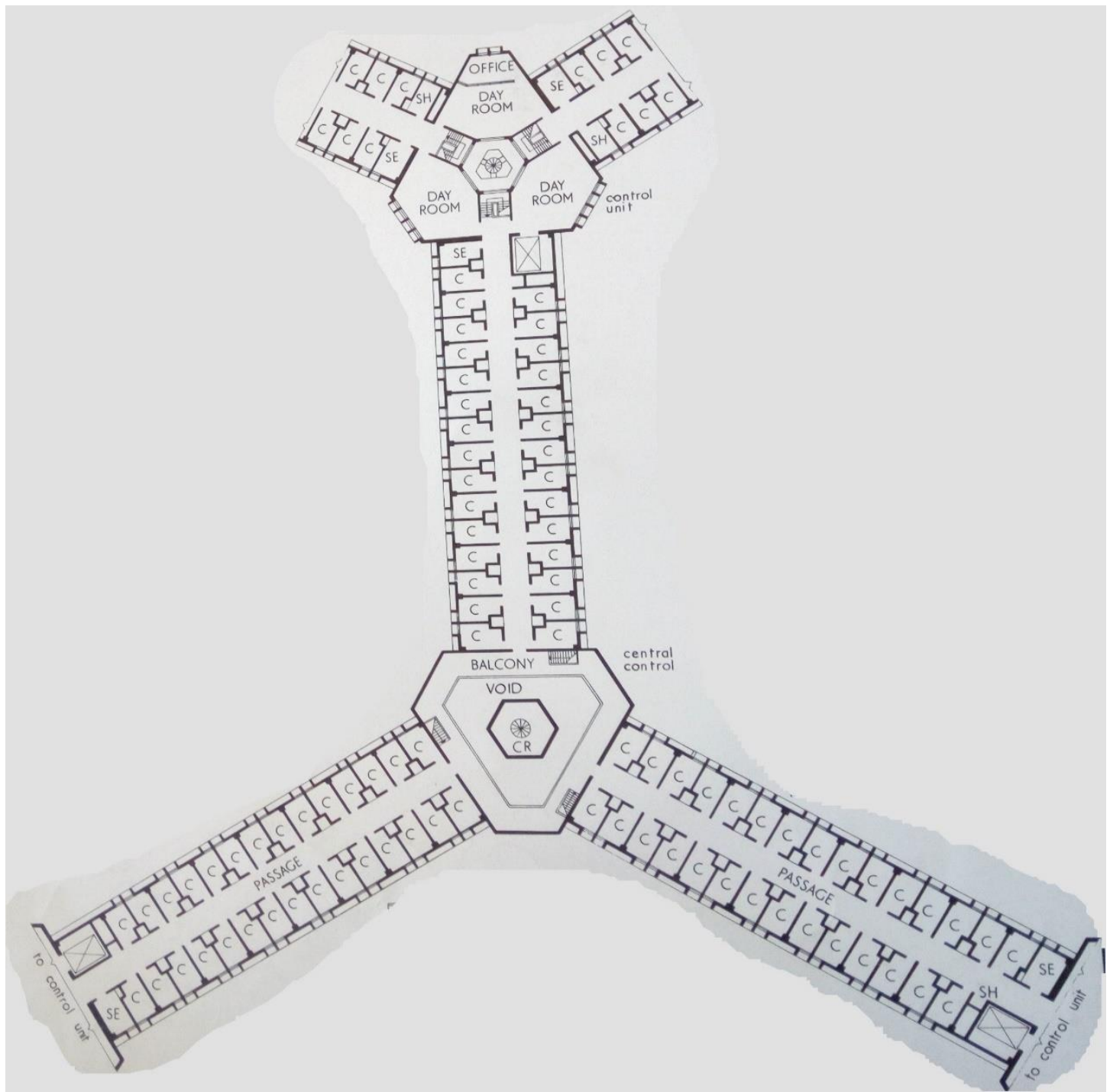

figure :2 master planning of main architectural

This allows viewing outside while preventing the possibility of communication with other prisoners. While the interiors are brightly colored and furnished with light wood, the predominant exterior materials are of fair-faced concrete and steel corten, which gives the building a strong and appropriately forbidden appearance.

It is also important to intensify initiatives to keep people out of prison, or to keep this time to a minimum, if they spend time in prison. In 2012, people sentenced to nine months or less can apply for community service. 
In 2016, this was extended to convicts for up to twelve months. Persons under the age of 21 usually serve no more than one third of the sentence in prison.

Electronic surveillance may also shorten prison sentences, where the mark is the price of early release. Another alternative entered the prison into force in 1995. Those prisoners approaching completion of a longer sentence or those who received a short sentence and received a steady job or education, are eligible for release from prison to serve their sentence in a halfway house. Run by a private non-profit association called Fernand in Reykjavik. There, guests pay rent and can take an external job or go to school and have more interaction with their families, but under strict codes of conduct (Gunnlaugsson and Galliher 2000). In 2014, 82 individuals served part of the prison sentence in Fernand (Prison and Monitoring Service 2016). Thus, we can say that keeping people out of prison remains the mainstay of Icelandic prison policy.

\subsubsection{Housing units:}

Inside a cell at Millhaven Penitentiary; the maximum-security federal penitentiary near Kingston; an inmate has room for a desk; chair and cot. But; prison officials and lawyers agree; inmates who try to use their time constructively are seldom encouraged and often harassed.

On September 30, 2013 Kingston Penitentiary was closed. Many maximum security inmates housed there were transferred to Millhaven. A new 96 bed facility was constructed within the Millhaven compound, to house inmates from the Kingston Pen closure.

\subsubsection{Security:}

The perimeter is surrounded by a double 30 -foot razor fence, and has observation towers at the corners.

A 4-foot "warning fence" inside the perimeter of the exercise yard acts as a boundary that inmates cannot cross without deadly force being used. Armed patrol vehicles with Colt Canada C7 rifles and parabolic microphones are on guard at all times. There are motion sensors in the outlying property, and multiple CCTV units throughout.

Visitors are subject to personal and vehicle search once on CSC property, and an ION scanner is used upon entry to detect drugs or other compounds on clothing or personal objects. The visiting area is equipped with CCTV, and listening devices are embedded in each table.

Inmates in the MAU (intake - A and E units) are allowed only screened visits, behind glass. 


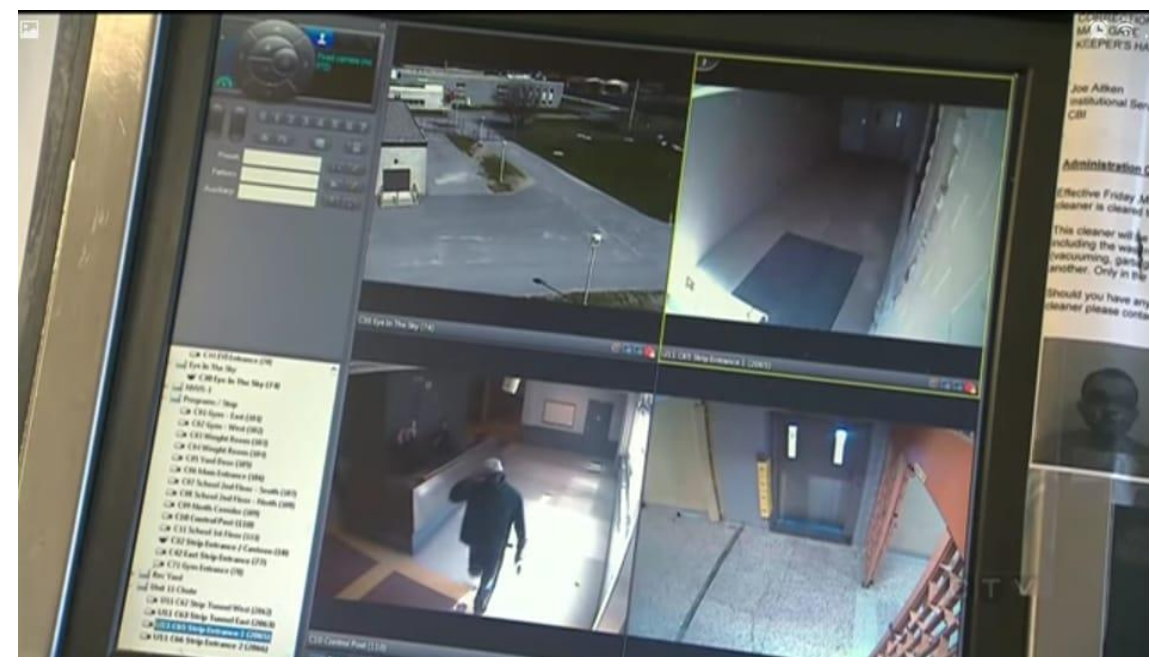

Figure 3 Security and control room

\subsubsection{Administration:}

In 1981, the Assessment Unit (AU) was relocated from Kingston Penitentiary to Millhaven Institution. Millhaven was home to the Kingston Immigration Holding Centre from 2006 until its closure in 2012. In 2010 the construction of three new Parole Officer Wings were completed at Millhaven Institution.

\subsubsection{The components of the prison and their areas:}

Table2: component's area

\begin{tabular}{|r|l|l|}
\hline no & Components & area \\
\hline 1. & Administration, visiting area, reception & 2458 \\
\hline 2. & Hospital & 6012 \\
\hline 3. & VIP area & 1030 \\
\hline 4. & Service area & 2056 \\
\hline 5. & Housing & 30150 \\
\hline 6. & Single officer accommodation building & 2756 \\
\hline 7. & Worden accommodation & 3457 \\
\hline Total area of established buildings & 47919 \\
\hline
\end{tabular}


Mohammed Saif EL-Nasr/Engineering Research Journal 166 (June 2020) A18-A33

Areas

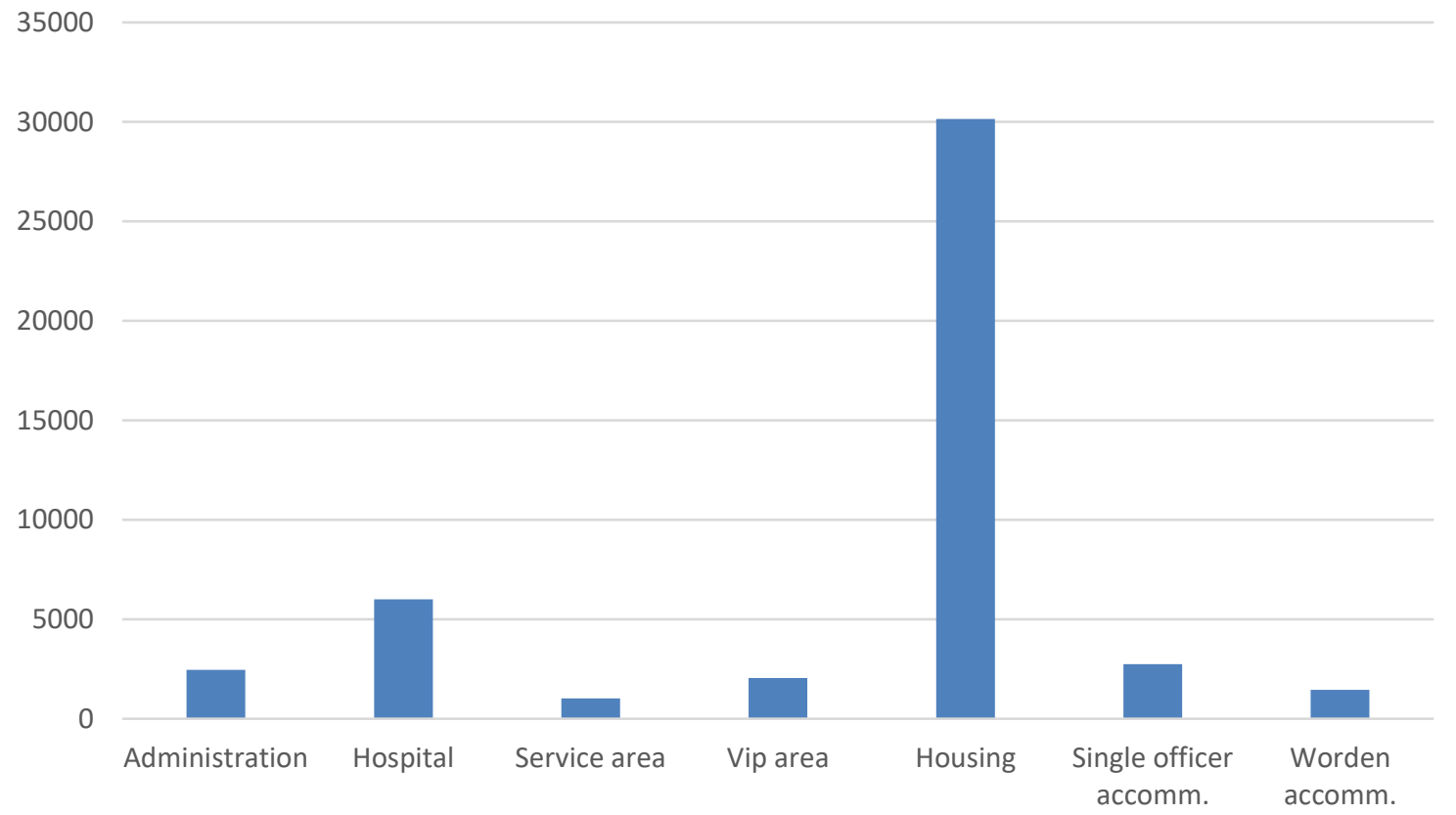

Aminsitration

\section{Ares}

Hospital

- Vip area

- Service area

Housing

口 Singlr officer accomm.

Worden accomm

Table3. The percentage area of the prison

\begin{tabular}{|r|r|r|r|r|}
\hline Users & Offers & inmates & visitors & Unused areas \\
\hline Specified area & $1.1 \%$ & $5 \%$ & $0.2 \%$ & $93.7 \%$ \\
\hline
\end{tabular}


The percentage area of the prison

\section{Specified area}

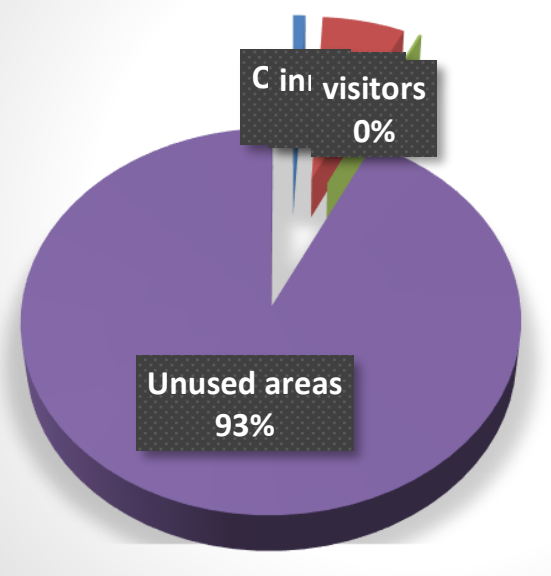

- Offers

n inmates

visitors

- Unused areas

\subsection{Tora from Prison based on the consideration of the Human Rights Organization:}

Tora prison is a political prisoner and an Egyptian criminal prison located south of Cairo. Throughout its history, it included a large and varied number of political currents and several types of criminals. The Tora Prison Complex includes the Mazraa Prison, Tora Lehman, Tora Reception Prison, Tora Sentenced, and the Tora Prison which is heavily guarded (known as "Scorpion Prison"). Tora Prison is located in front of Tora Al-Balad Metro Station in Tora, southwest Helwan, in Cairo Governorate.

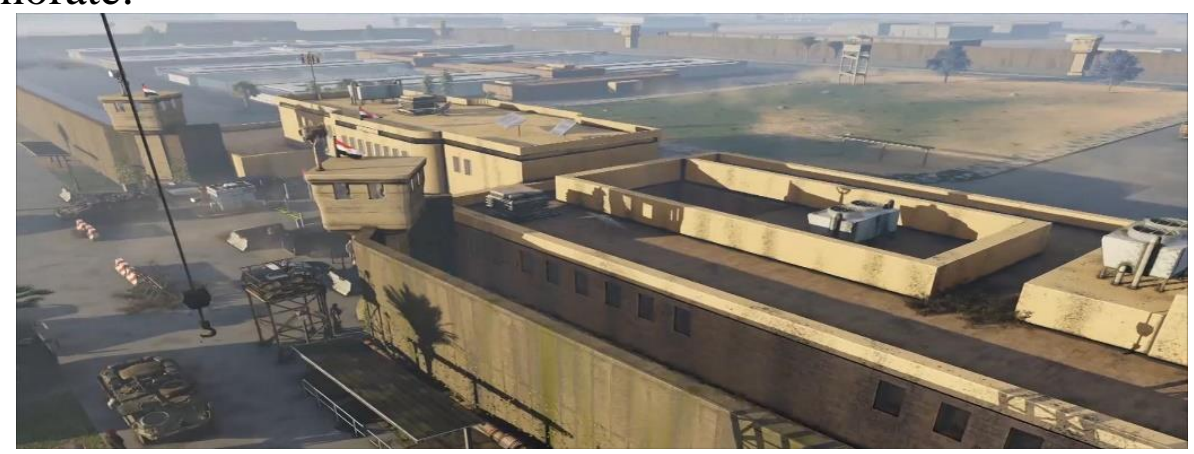

Figure 1 Tora prison 


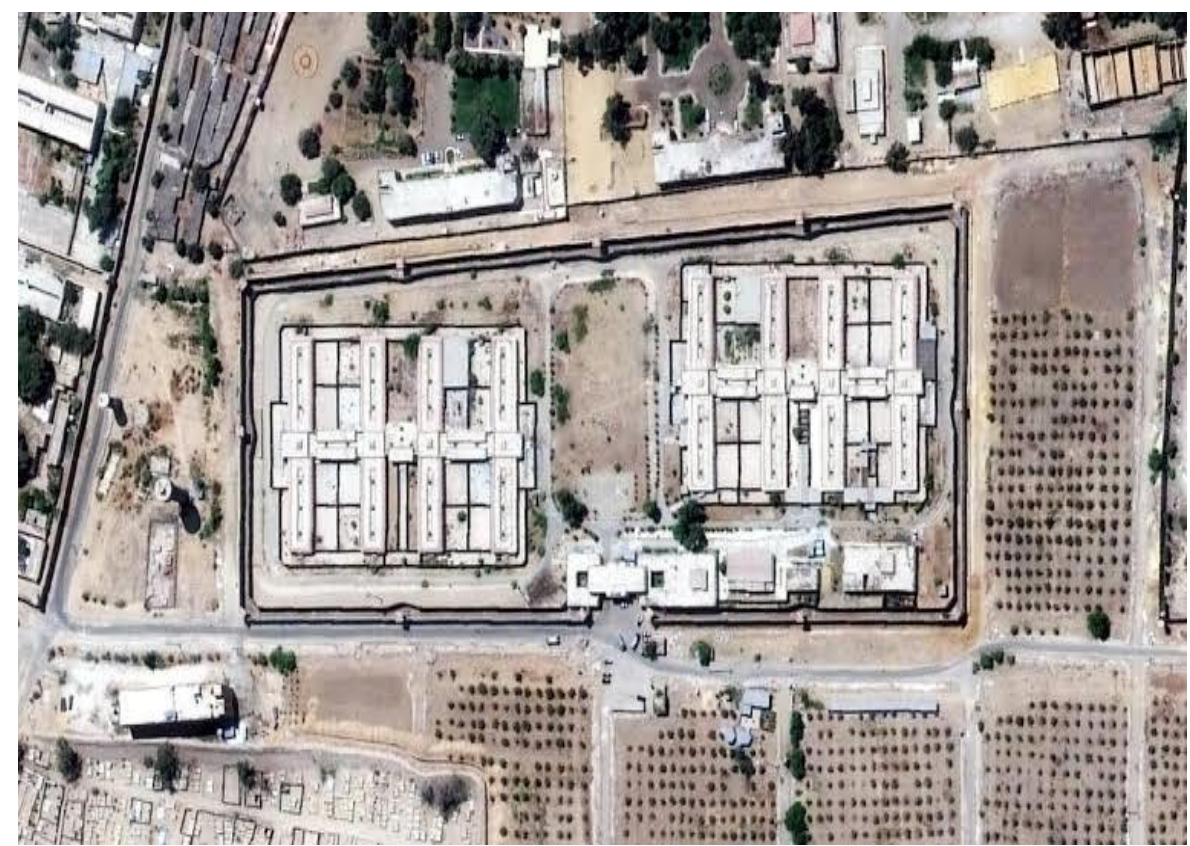

Figure 2 Tora prison layout

\subsubsection{Site consideration:}

Tora Prison is located in front of Tora Al-Balad Metro Station in Tora, southwest Helwan, in Cairo Governorate. Much of the prison is located directly on the Nile and is surrounded by a group of police officers' towers that were built in 1997, to be the tallest buildings facing the prison. The following figure shows a map showing the location of the prison.

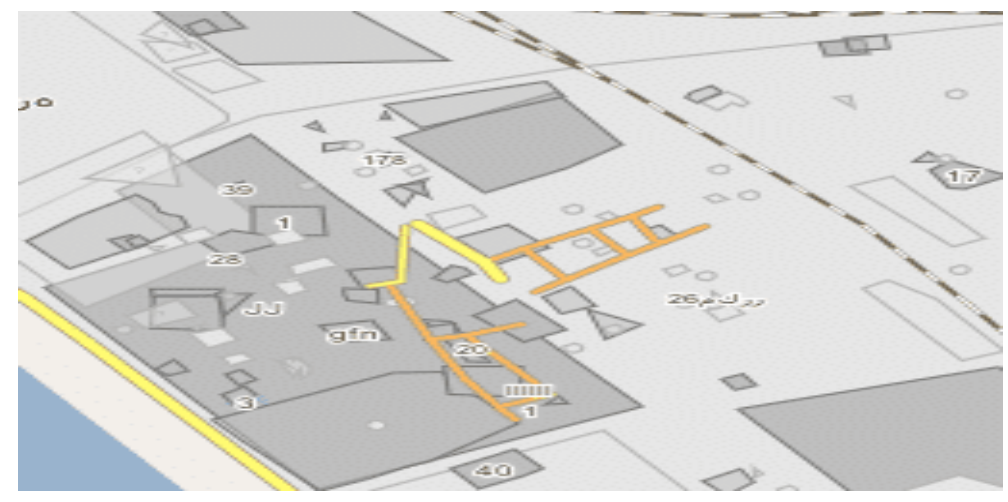

Figure (3) Google maps showing the location of Tora prison

\subsubsection{Prison components:}

\subsubsection{The main parts of Tora from Prison " $A$ ":}

* Entrance

* Stadiums

*Mosque

*Library

* Prison cafeteria 
* Elvis and the hospital

* 40 observation towers (approximately)

* Tora farm prison

* Disciplinary ward

* Solitary confinement (the cell is narrow and the visit is prohibited, as shown in the following figure)

* Dormitory 1 ("Celebrities" or "Tora Land" is for those accused in cases of public funds)

* Dormitory 2 ("Repentant" is for Islamic groups and the Muslim Brotherhood)

* Block 3 (for convicts, police officers and judges in bribery cases)

*Dormitory 4 (for persons accused of criminal and drug cases)

\subsubsection{The Tora from Prison Area "B":}

The area of zone $\mathrm{B}$ of Tora prison is approximately 50 acres, divided into:

1- Main entrance

2- Farm prison

3- Umbrella, walkway and gathering places for those who want to visit

4- Ward of agriculture

5- Mosques and administrative offices

6-soccer field and park

7- Tora Public Prison

8- Tora reception prison

9- High-security prison "Scorpio"

10-rooms and offices for the prison's central administration

11- 200 observation towers (approximately)

12-central islands "cultivated", 15 centimeters high

13- 2 Golf car the first with 12 vehicles and the second with 8 vehicles to move in the wide prison area.

\subsection{Master planning:}

Tora prison consists of seven blocks each holding approximately 350 prisoners, and are divided into sections such as political prisoners and criminals according to the severity of their crimes. There is a block for police officers and judges imprisoned on bribery charges, and a disciplinary block consisting of seven solitary confinement cells, two meters squared in size and some without light or ventilation. The prison walls are seven meters tall and are monitored by CCTV. The different sections of the prison are walled off from each other. After three prisoners from the Egyptian Islamic Jihad organization implicated in the assassination of Anwar Sadat escaped in 1988, 2.5 meters were added 
to walls. Tora Prison has a small hospital overlooking a garden which is the block where businessmen and members of the Mubarak regime are held for corruption cases. The hospital is next to a football pitch and to a tennis court where the prisoners exercise.

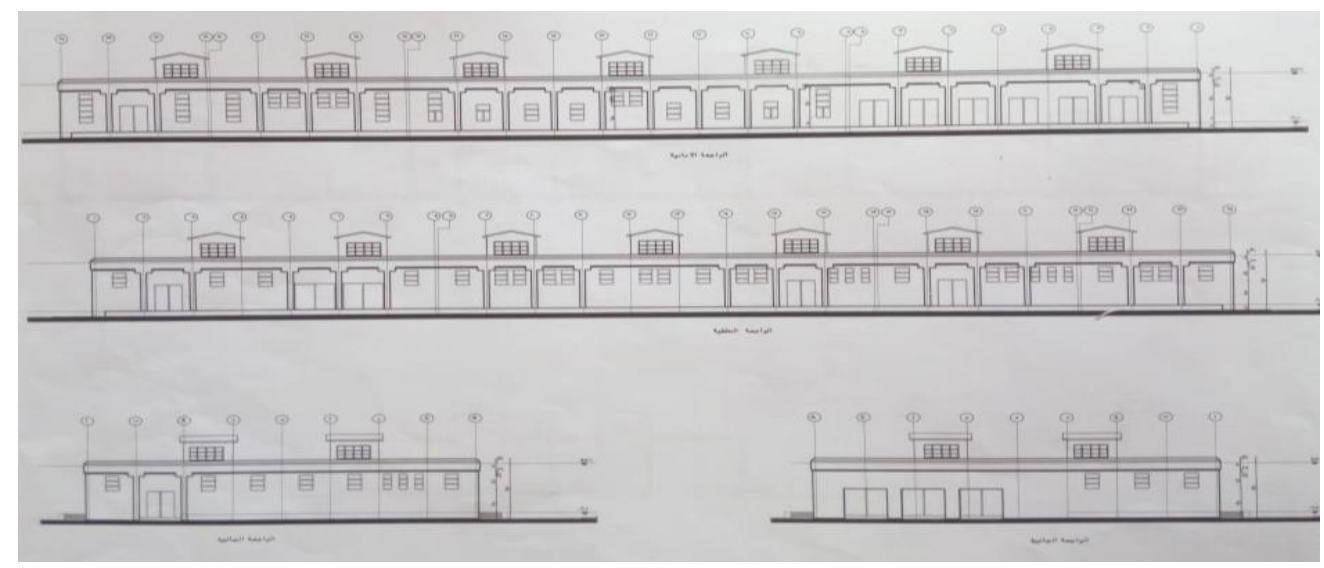

Figure (4) Tora prison elevations

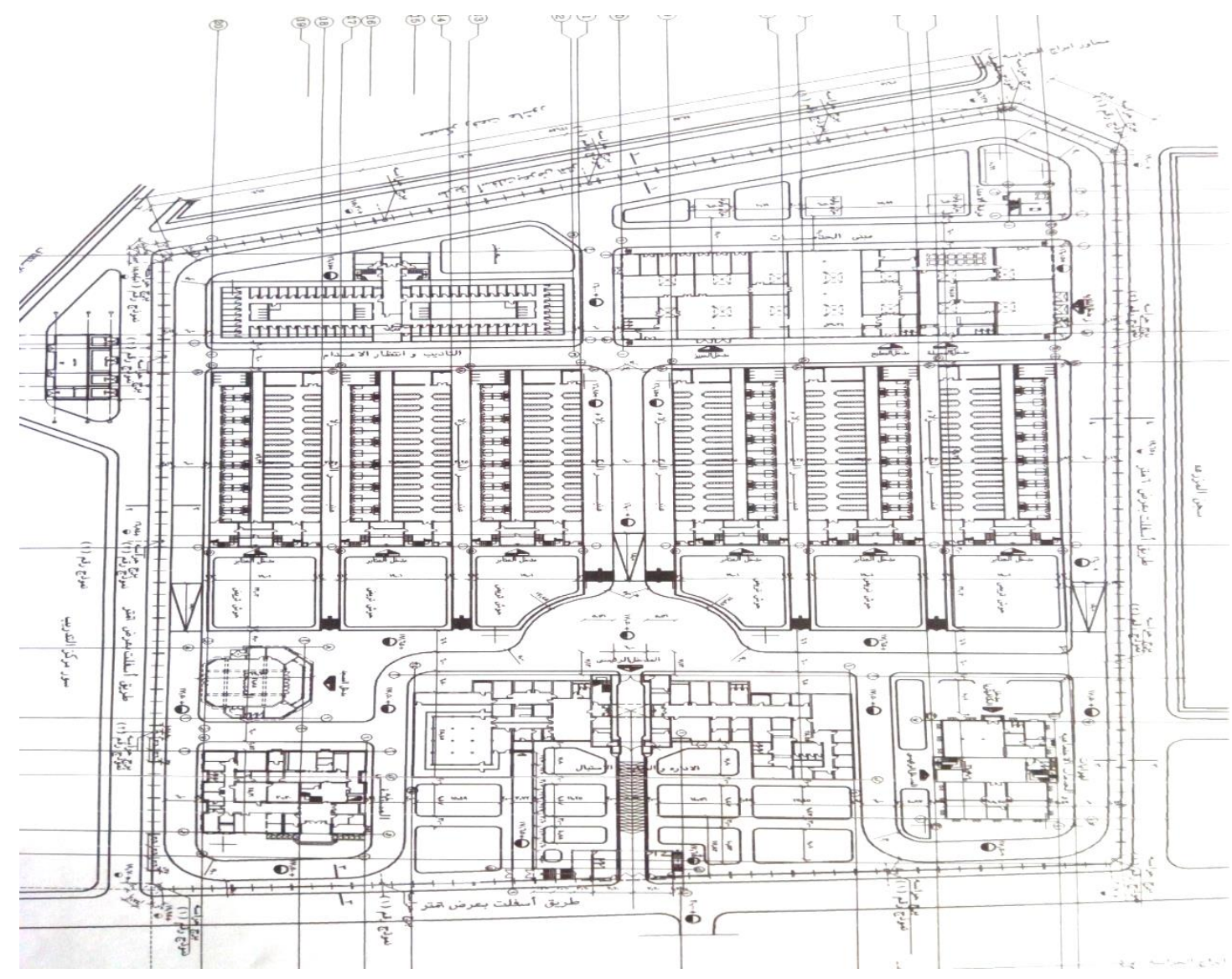

Figure 3 Farm Tora prison

\subsection{Tora Prison developments throughout history:}

Tora prison has gone through many stages over the past eight decades and has always been associated with opposition and opposition currents and events affecting the history of Egypt, beginning with the royal era in 
which the prison was established, through the republican rule that witnessed a huge development in the detention facilities and method in Egypt. The establishment of Tora Prison dates back to 1928 by a decision of Mustafa El-Nahhas Pasha, the Minister of Interior at the time, with the aim of relieving the crowds in the "Abu Zaabal" prison. Over time, the prison expanded to include 7 prisons, including Al Mazra'a Prison, Tora Liman, Tora Reception Prison, Tora Prisoners, and Tora Prison, which is very well-known and famous for scorpion.

The development stages of Tora prison were related to the nature of the era and the amount of pressure and persecution of politicians and hardline religious groups. With the beginning of the royal era, the prison witnessed a decline in the level of its facilities, and neglect in its methods of protection and security, passing through the period between the July Revolution and January 25 in 2011.

Despite this, Amnesty International has received information that a number of new prisoners have been subjected to electric shocks, a number of forms of torture and ill-treatment, along with solitary confinement for years.

\subsection{Visit:}

The visitor goes directly to the prison headquarters and expresses his desire to the prison delegate in the place designated for that in the public portal to visit a guest.

\subsubsection{Private visit:}

1- Every prisoner, regardless of his punishment, is permitted "a special visit once a month", and care should be taken not to allow private visits to categories of convicts in some crimes harmful to state security.

2 - The visitor fulfills the request for conducting the private visit and submits it to the prison administration after paying the legally prescribed fees, and notifies the student immediately of whether the visit is due.

3- The prison warden may allow prisoners in one prison to visit some of them within the limits prescribed for the regular visit. The visit takes place in the assistant office and in his presence. It is not permissible to allow a prisoner to visit a prison unless his wife or a mahram is for her.

\subsection{Insurance methods:}

1- Tightening control from inside and outside.

2- Crisis management rooms headed by the sector.

3- Developing prison insurance plans.

4- Electronic control through television monitoring.

5- Developing metal detectors.

6- Use of cavalry, camel and security dogs. 


\subsection{Tora ... from the inside:}

The Tora farm prison gained wide fame after the symbols and leaders of the former regime became guests, which aroused the curiosity and desire of many to know the details of what is going on behind its high walls. The prison "months" is currently, although it is among the 7 other prisons in the central area of prisons, it differs greatly from others, and this may be due to the "nature" of the inmates there.

\subsubsection{Reception:}

It is located in Tora prisons area, and there are 3 wards A, B and C wards, in addition to the disciplinary ward with more than 1,600 detainees and the first two wards are multi-story wards and includes individual cells in the first and group floors in the rest of the floors, and Wards $\mathrm{C}$ consists of one role built with concrete Armed, and non-ventilated, it is a newly built ward, and it is called a highly guarded ward.

\subsubsection{Healthcare:}

The Tora Lehman Hospital is located inside Tora Lehman, which is a separate ward of $30 \mathrm{~m} \times 20 \mathrm{~m}$. The ward is divided into two separate floors, the first floor is reserved for criminal prisoners, and the second floor is reserved for political prisoners, and inside the hospital ward there is a bathroom with a municipal base, the other is a septic tank and a water basin.

\subsubsection{Security:}

A high-security prison is located at the end of the Tora prison area, about $2 \mathrm{~km}$ from the door to the area, and preceded by arranging the Tora reception prison, Tora farm prison, and the farm attachment prison on AlOtostrad Road. The prison was completed on 30/5/1993 and opened on 6/26/ 1993 Inmates were transferred to AbuZaabal Prison, Iqbal Tora, and Lehman Torah.

\subsubsection{Housing units:}

The prison contains 320 cells divided into 4 wards, and each ward contains 80 cells in the shape of the letter $\mathrm{H}$, and the area of the cell is 2.5 meters $x 3$ meters and a height of 3.5 meters, and each cell has a window of length and width $90 \mathrm{~cm} \times 80 \mathrm{~cm}$ and the height from the ground is 2.5 meters and the window overlooks a walled road above the ceiling Concrete, and the fence has holes at a height of three meters from the surface of the earth through which air and the sun enter indirectly, as the cell window deviates from the hole shown with a distance of 1.5 meters, and the cell has a steel door of 2 meters in height and one meter in width and has an opening at a height of 1.5 meters in length and width $25 \times 15$ 
$\mathrm{cm}$ inside each dungeon of an electric spotlight with a 100-watt bulb and lighting controls A via the external control room.

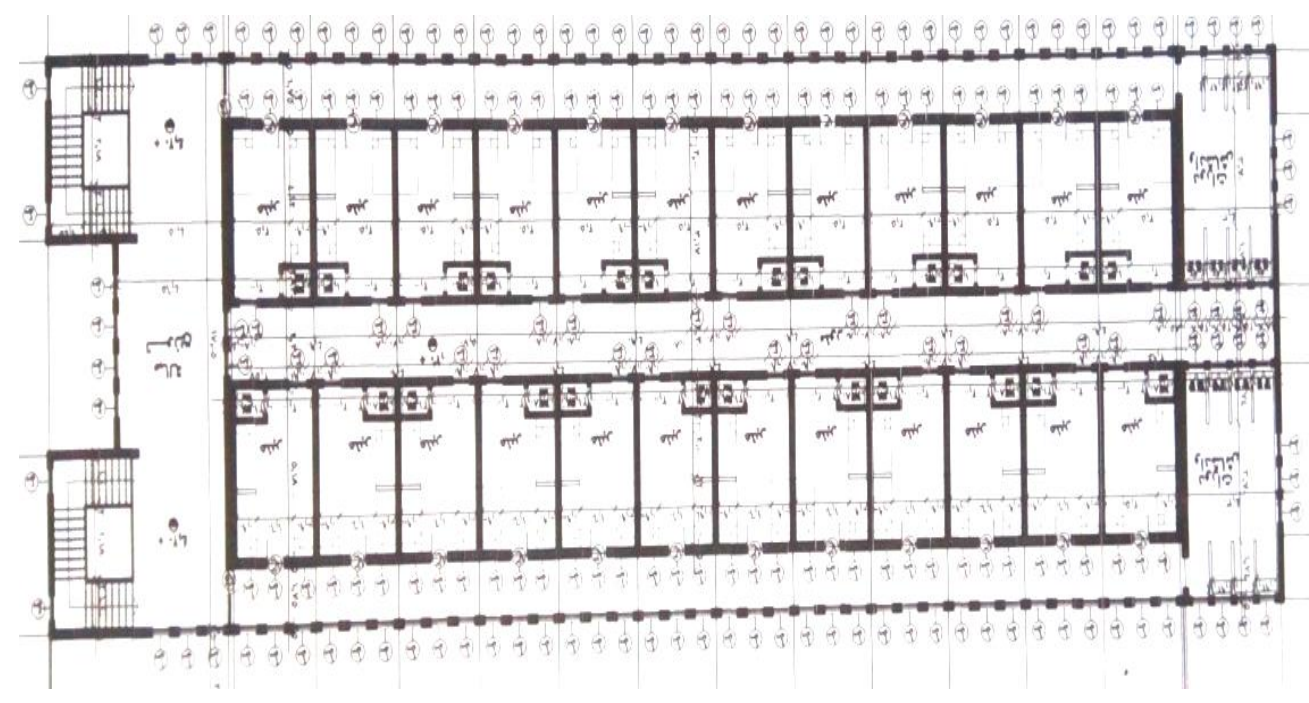

Figure (6) Typical cells floor

\subsection{The components of Tora prison and their areas:}

Table 2: Area of components

\begin{tabular}{|r|l|l|}
\hline no & Components & area \\
\hline 1. & Mosque & $0.1 \mathrm{~km}$ \\
\hline 2. & Prison Hospital & $0.7 \mathrm{~km}$ \\
\hline 3. & Services area & $0.5 \mathrm{~km}$ \\
\hline 4. & Amber Rooms & $0.6 \mathrm{~km}$ \\
\hline 5. & Mess, Buffet and Library & $0.6 \mathrm{~km}$ \\
\hline 6. & Dormitory B & $0.3 \mathrm{~km}$ \\
\hline 7. & Reception of Dormitory B & $0.2 \mathrm{~km}$ \\
\hline 8. & Single officer accommodation & $0.4 \mathrm{~km}$ \\
\hline 9. & Worden accommodation & $0.7 \mathrm{~km}$ \\
\hline The total area of established buildings & $4.1 \mathrm{~km}$ \\
\hline
\end{tabular}




\section{Area of components}

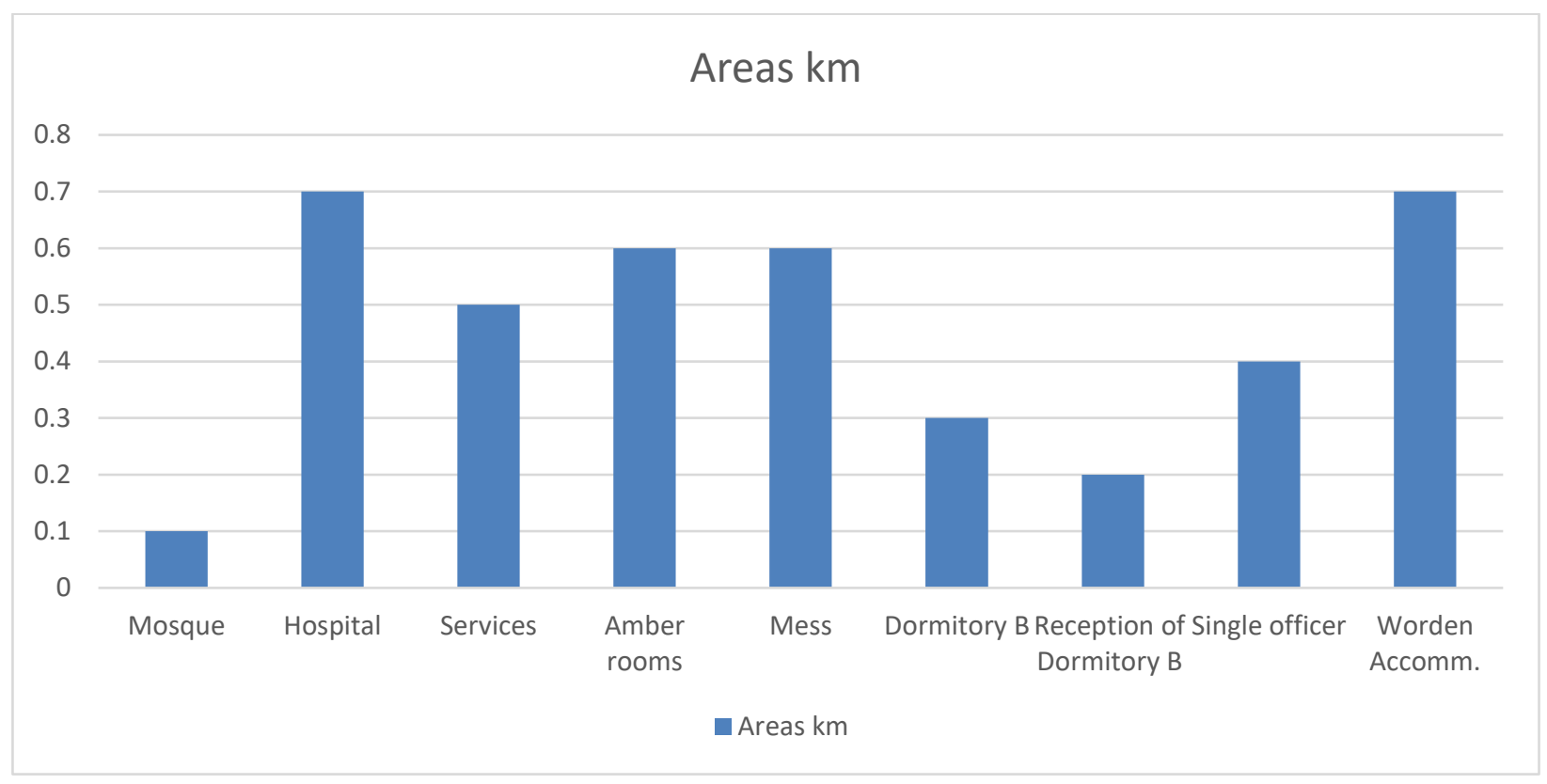

Figure (6) Area of components

Table1: The percentage area of the prison

\begin{tabular}{|r|r|r|r|r|}
\hline Users & Officers & inmates & visitors & Unused areas \\
\hline Specified area & $4 \%$ & $33 \%$ & $0.3 \%$ & $62.7 \%$ \\
\hline
\end{tabular}

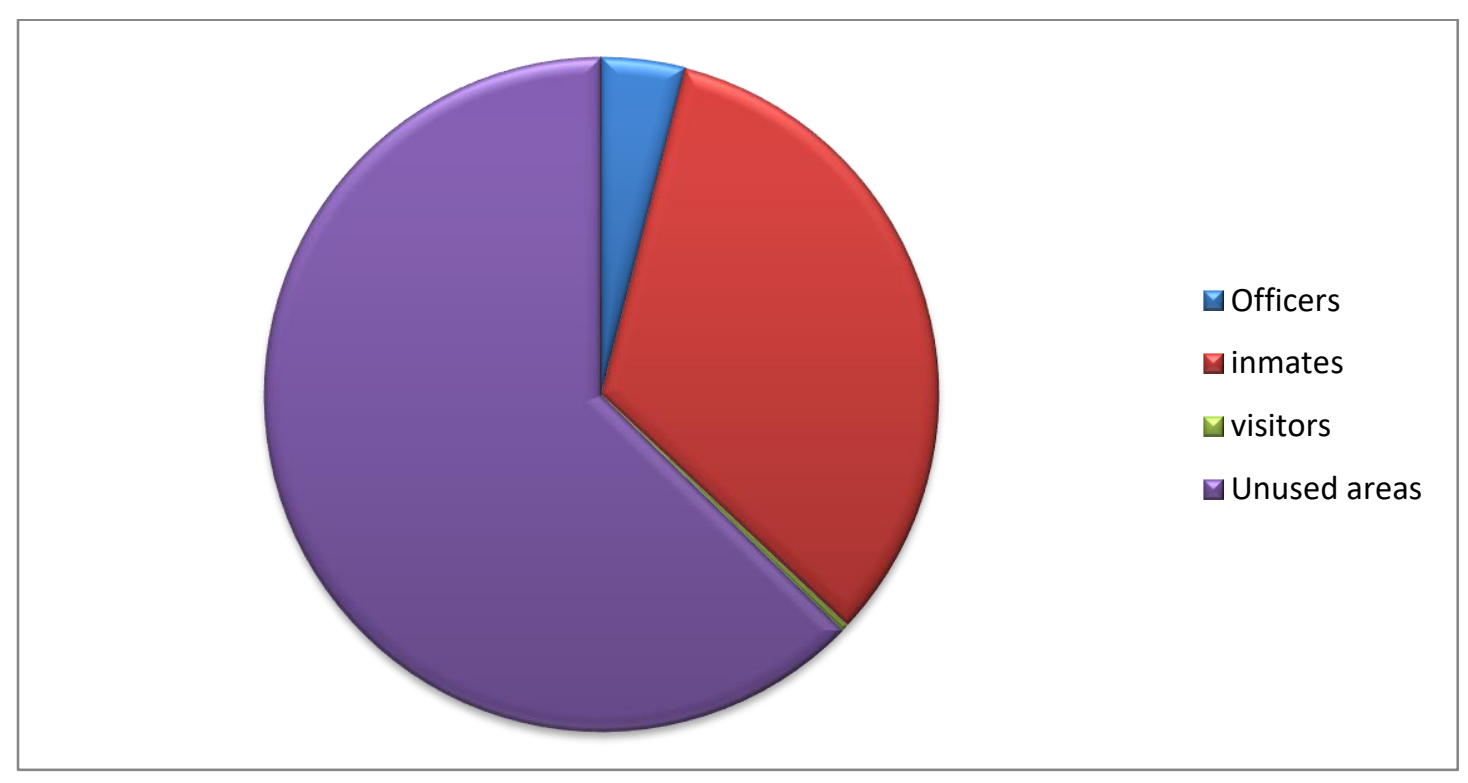

Figure (7) The specified area of the prison 


\section{Results:}

From the previous presentation of the two cases, it can be said that a prison of (Millhaven Institution - Island 2012 ) was designed based on the considerations contained in the human rights agreements for the prisoner's enjoyment of human rights, as the choice of the place on which the prison was built was based on environmental considerations that make the prison site a distinguished location in terms of mild climate, and with respect to the basic design, The designer takes into account good ventilation, good lighting and other human considerations.

The right to proper and adequate healthcare for prisoners is a right guaranteed by international human rights conventions. Nevertheless, it is hardly applicable to Egypt. Despite the presence of articles in the Egyptian Prison's Law which guarantees the right to healthcare. For example, Article 33 states that "In any prison or hard labor prison, there should be a physician or more than one; at least one has to be permanently resident." Also, Article 36 of the same law states, "Any convict who is suffering from a life-threatening or crippling disease as verified by the prison's doctor will be presented to the Director of the Medical Section in Egyptian prisons who will, with the help of a forensic doctor, look into the decision to release the patient. The release order will be activated following the signature of the General Director of the Prisons Authority and the approval by the General Prosecutor." The administrative authority and the concerned prosecutor are also informed of the release.

Yet, in practice, the deterioration of the Egyptian prisons is further exacerbated by the quality of medical services and the lack of medical equipment required for dangerous and advanced diseases that require precise testing and observation. Some Egyptian prisons even lack pharmacies with adequate medical supplies. Some do not have a residing physician.

Frequently, cleaning is a source of income in prison. Thus, prisoners clean cells or wash clothes and other items for the wealthier inmates in exchange for a fee. Although this further deepens class divisions in correctional facilities, it cannot be denied that such professional relationships create an income for a significant sector of detainees that sustains them in prison.

According to the findings of the research, sanitary facilities in prisons are not of a standard that guarantees a dignified, healthy use without risk of disease. This is closely related to the difficulty of accessing water.

Research participants held diverse opinions about the cleanliness and privacy of sanitary facilities. Due to overcrowding in most prisons, rooms not designed as cells were nevertheless used for this purpose. Thus, 
prisoners must wait long periods if the doors are closed to reach sanitary facilities or access water, whether for drinking or cleaning.

Moreover, for detainees, the existence of a toilet in the room or ward was considered a key indicator of the humaneness of the prison. It is also a factor that attracts powerful inmates to particular prisons, leading them to request transfers to such facilities.

In prisons without toilets in the rooms, prisoners cannot go to the toilet except when the cell doors are opened at specific times set by the prison administration, which may be changed to punish and degrade prisoners.

Lighting inwards and prison rooms are weak to non-existent. The former inmates described windows of various sizes. Some were high and small like a transom, while some prisons had very large windows measuring 2 by 1 meter, according to a former prisoner in the Port Said Women's Prison. Another window was described as very narrow but extending across the room $(2 \mathrm{~m}$ by $30 \mathrm{~cm})$.

All windows were covered with layers of wire mesh for security purposes, which had been filled in with dust and cobwebs, thus permitting no light and air to pass through.

Most former inmates stated that they did not have enough light to read; only very few could read because they were held in rooms with big windows.

Nonetheless, large windows caused problems in winter, as they were not sealed against the cold.

Article 29 of the Egyptian Prisons' Law states that there should be a curriculum devised for the detained as a result of the cooperation of the Ministry of Interior and the Ministry of Education. Article 31 of the same law states that the prison's administration is responsible to secure the prisoners' learning process. Thus it is the right of the prisoners to join schools and colleges. It is also their right to either take the necessary exams during their imprisonment. Our reports and rulings of the administrative court have pointed to the fact that the Ministry of Interior continues to violate this right by preventing the distribution of school books to political detainees and preventing them from taking exams due to issues such as security or that their universities lie outside the constituencies of the prisoner's detention center. Sometimes the prison's administration receives books for prisoners from their families, but destroy them as a form of an illegal and unjustified punishment

\section{5-CONCLUSION:}

First: The positive aspects of the design of Tora farm prison

- In terms of location, the choice of place was suitable for ventilation, lighting. 
- The visitor goes directly to the prison headquarters and expresses his desire to the prison delegate in the place designated for that in the public portal to visit a guest.

Secondly: The negative aspects to the design of Tora farm prison according to human rights considerations

- The right to proper and adequate healthcare for prisoners is a right guaranteed by international human rights conventions. Nevertheless, it is hardly applicable in Tora farm prison

- Cleaning is a source of income in prison. Thus, prisoners clean cells or wash clothes and other items for the wealthier inmates in exchange for a fee. Although this further deepens class divisions in correctional facilities.

- Lighting inwards and prison rooms are weak to non-existent

\section{RECOMMENDATIONS:}

- Emphasizing the necessity of applying the determinants upon which the research was based, necessary to implement the standards of the human rights organization when designing prison buildings

- Work to provide knowledge of new technologies in the field of prison design and demonstrate their advantages in design while highlighting the dimensions of the implementation of the crossings of human rights organizations

- Doing joint research between the different engineering disciplines to develop the capabilities and means of applying the standards mentioned in the international human rights agreements. 


\section{REFERENCES:}

]$^{1}[$ Jewkes, Y., \& Johnston, H. (2012). The evolution of prison architecture. In Handbook on prisons (pp. 204-226): Routledge

]$^{2}[$ Jewkes, Y., Crewe, B., \& Bennett, J. (2016). Handbook on prisons: Routledge

]$^{3}[$ Moran, D., \& Jewkes, Y. (2015). Linking the carceral and the punitive state: A review of research on prison architecture, design, technology and the lived experience of carceral space. Paper presented at the Annales de géographie.

${ }^{4}$ [ ]Salle, G. J. P. (2012). De la prison Dans la Ville à la prison-Ville. (1), 75-98.

5[ ]Dikötter, F. (2018). Cultures of confinement: a history of the prison in Africa, Asia, and Latin America: Cornell University Press.

]$^{6}[$ Mandela Rules, Rule12 / IACHR, Principle XXII / European Court of Human Rights. Van der Venv. the Netherlands. 2003. No. 50901/99, para51./ Bangkok Rules, supra note 13, rule 5; EPRs, supra note 24, rule 19.7; Principles and Best Practices of the IACHR, supra note 4, princ XII/ Body of Principles, Principles 15 and 19; EPRs, Rule 99; Principles and Best Practices of the IACHR, Principle XVIII; ICCPED, Article 10/ Basic Principles, 5; ICESCR, Article 13/ UN Committee on Economic Social and Cultural Rights. General Comment No. 13: The right to education (Art. 13 of the Covenant). 1999. 